\title{
Extraction of rare earths from iron-rich rare earth deposits
}

\author{
by K. Bisaka*, I.C. Thobadi*, and C. Pawlik*
}

\section{Synopsis}

Rare earth metals are classified as critical metals by the United Nations, as they have found wide application in the fabrication of magnets, particularly those used in green energy technologies which mitigate global warming.

Processing of ores containing rare earth elements is complex, and differs according to the nature of each ore. In the conventional process, run of mine (ROM) ores are processed in a physical separation plant to produce a concentrate from which rare earth elements are extracted via a hydrometallurgical route. To extract rare earth elements economically, multiple sequential physical and chemical separation steps are used to produce a mixture of rare earth salts, followed by purification and production of metals and alloys.

Large iron-rich rare-earth-bearing deposits exist in China, Southern Africa, Canada, and Australia. Although these deposits carry significant reserves of rare earth elements, a number of them are not exploited as no economically viable process exists to do so. The mineralogy of the difficult deposits is complex, with rare earth minerals of particle size less than $20 \mu \mathrm{m}$ disseminated in a matrix of iron oxide such as haematite, magnetite, or goethite. A process comprising fine milling for liberation of rare earth minerals, and physical upgrading of the resulting materials, would be technically challenging, inefficient, and not economically viable. Globally, research efforts are directed towards the development of novel methods and new reagents to overcome these difficulties.

PyEarthTM is a novel process currently under development at Mintek, that is aimed at achieving efficient extraction of rare earths from the mineralogically complex iron-rich, rare-earth-bearing ores. The process incorporates a preliminary smelting step to reduce the iron to the metallic state and concentrate the rare earths into the slag phase, followed by leaching of the slag and recovery of the rare earths from the leach liquor. Tests at the laboratory scale on samples from deposits originating from Southern Africa have proved that the extraction of rare earths from iron-rich, rare-earth-bearing ores using this process is technically feasible, robust, and viable.

Keywords

PyEarthTM, iron-rich rare-earth-bearing ore, direct smelting, rare-earthrich slag, hydrochloric leaching, rare earth.

\section{Introduction}

The rare earths are listed amongst the strategic metals by the United Nations because of their properties and increasing usage (Long et al., 2010). Among many possible applications, rare earths are used to sustain today's lifestyle through the manufacture of magnets, catalysts, weaponry, production of green electricity, etc.

Current global production is about $130 \mathrm{kt} / \mathrm{a}$ of rare earth oxides (REO), with about $90 \%$ of this coming from China. Consumption of rare earths is projected to increase at a rate of 6$10 \%$ per annum and could reach $200 \mathrm{kt} / \mathrm{a}$ in the very near future (Long et al., 2010; Haque et al, 2014; Wang et al., 2015; Li and Yang, 2014). More than $50 \%$ of today's global consumption of rare earths is currently located in China.

The proven global rare earth reserves are estimated at about $110 \mathrm{Mt}$ of REO (Wang et al., 2015). China's resources of rare earths are the largest and are estimated at about $48 \mathrm{Mt}$ of REO or about $43 \%$ of the global reserves. Other rare earth resources are located in Russia (17.3\%), the USA (11.8\%), Australia, India, Brazil, and Greenland (Gupta and Krishnamurthy, 2004). Placer deposits of ilmenite as well as phosphate deposits are also considered to some extent as resources of rare earths. Placer deposits that predominantly contain monazite are mainly found in Australia, India, South Africa, Mozambique, Kenya, and Malawi. Historically, rare earths have been produced in South Africa and (sporadically) in the Democratic Republic of Congo. As reported by Gupta and Krishnamurthy (2004), Namibia has the second largest reserve worldwide with about 20 Mt REOs, and South Africa has about $1 \mathrm{Mt}$. Despite the existence of large deposits, Africa's contribution to the global supply of rare earths is insignificant.

Production of rare earths from ores involves a complex process that is designed according to the nature and mineralogy of each ore deposit. Basically, run-of-mine rare-earthbearing ores are beneficiated by physical methods into a concentrate that is leached to extract the rare earth species. In very few situations, an in-situ leaching process (also

* Mintek, Randburg, South Africa.

(C) The Southern African Institute of Mining and Metallurgy, 2017. ISSN 2225-6253. This paper was first presented at the Hydrometallurgy Conference 2016 'Sustainable Hydrometallurgical Extraction of Metals', 1-3 August 2016, Belmont Mount Nelson Hotel, Cape Town. 


\section{Extraction of rare earths from iron-rich rare earth deposits}

called solution mining) is carried out in which the leaching reagent is injected into wells drilled in the orebody to selectively leach the rare earth species, and the leachate is collected, thus minimizing environmental pollution ( $\mathrm{Li}$ and Yang, 2014). Rare earths are extracted from the leachate and transformed into pure rare earth oxides, chlorides, or halides by hydrometallurgical means. Pure rare earth metals and rare-earth-metal alloys are produced by direct reduction of rare earth oxides, reduction of anhydrous chlorides and fluorides, and fused salt electrolysis of rare earth chlorides or oxide-fluoride mixtures. Pure rare earth oxides may be prepared by selective oxidation, selective reduction, fractional crystallization, ion exchange, and solvent extraction.

Chlorides and fluorides are produced by transformation of rare earth oxides (Gupta and Krishnamurthy, 2004; Mishra and Anderson, 2014).

A rare earth deposit is valuable only when the metal values can be extracted in a cost-effective, efficient, sustainable, and environmentally responsible manner. Although a large number of deposits have been explored worldwide, only a few are mined for rare earths. The most prominent rare earth mining operations are Bayan Obo in China, Mount Weld in Australia, and Mountain Pass in the USA, which has been on care and maintenance since 2015 (Haque et al., 2014; Li and Yang, 2014).

Bayan Obo is the largest exploited iron-rich rare earth deposit. The ore contains up to $6 \% \mathrm{REO}$ and $35 \% \mathrm{Fe}$. More than $90 \%$ of the rare earth elements (REE) in the ore exist as independent minerals, and about $4-7 \%$ of the total rare earth minerals are disseminated in the iron oxide minerals. The Bayan Obo deposit contains bastnaesite and monazite, with magnetite and haematite as the dominant iron ore minerals. This ore is upgraded to a $65 \%$ REO concentrate with an overall rare earth recovery of about $61 \%$ via a complex beneficiation process. The milled ore, $90-95 \%$ passing $74 \mu \mathrm{m}$, is submitted to low-intensity magnetic separation (LIMS) and high-intensity magnetic separation (HIMS) to produce a mixed concentrate containing about $9.78-12 \%$ REO. The mixed concentrate is subjected to a HIMs cleaner stage to separate the haematite, which is recovered by reverse flotation, while the HIMS cleaner tails, containing most of the rare earth minerals, are beneficiated by flotation to obtain a high- $(60 \%$ REO) and a low- (>30\% REO) grade concentrate. This is followed by selective flotation to separate bastnaesite and monazite. Higher recoveries of up to $75 \%$ can be achieved at a lower concentrate grade (Li and Yang, 2014).

The Mount Weld mine, which was opened in 2011, exploits one of the world's highest grade rare earth deposits, with an average REO grade of $15.4 \%$. Mount Weld has been described as a secondary rare-earth phosphate deposit, but the phosphates (most likely monazite) are encapsulated in iron oxide minerals (Haque et al., 2014). Mount Weld produces a rare earth concentrate and an iron ore concentrate for further beneficiation.

Upgrading of some of the rare earth ores is challenging, due to the complexity of the mineralogy. This was the case for two specific iron-rich rare earth deposits in the Southern African region. Milling was not able to liberate the rare earth minerals from the iron mineral matrix. In this paper we present the results of an investigation into the processing of iron-rich rare-earth-bearing ores from the Southern African region.

\section{Process overview - iron-rich rare-earth-bearing ores from Southern Africa}

\section{Brief mineralogy and implications}

Two samples of iron-rich rare-earth-bearing ore from two deposits in Southern Africa were evaluated. In both samples, the bulk of the REE are contained in monazite minerals less than $20 \mu \mathrm{m}$ in size. Rare earth mineralization occurs as coatings on haematite/goethite or as grains disseminated in the haematite/goethite matrix. The ores also contain bastnaesite, synchysite, ancylite, pyrochlore, REE-apatite, and rhabdophane. Quartz, jarosite, svanbergite, apatite, barite, mica, clays, crandallite, gorceixite, carbonates, and nordite are present as gangue minerals. Monazite and ancylite often occur as submicroscopic inhomogeneous grains in association with Fe-oxyhydroxides. Ancylite is associated with calcite and apatite. The main Fe-carbonate minerals are dolomite/ankerite, with minor calcite and $\mathrm{Fe}$-oxyhydroxides. The gangue contains REE minerals less than $10 \mu \mathrm{m}$ in size.

Fine milling to below $20 \mu \mathrm{m}$ to liberate the rare earth minerals in order to selectively separate them (principally from haematite or goethite) was extensively investigated by Mintek's Mineral Processing Division. Most of the conventional physical separation techniques were found to be inefficient.

Globally, research efforts are directed towards the development of novel methods and new reagents to overcome these difficulties. Bulk leaching of these ores to extract rare earths inevitably solubilizes iron minerals and increases acid consumption. Removal of the iron from the leachate requires excessive amounts of reagents such as lime. This, in addition to the discarding of the iron precipitate, increases the cost of the process, usually beyond economic viability. Methods for extracting rare earths without affecting the value of the iron minerals are required to improve the economics of processing these ores

\section{High-temperature processing of iron-rich rare earth ores}

Separation of iron and rare earths is theoretically possible by carbothermic reduction and could be an alternative to physical upgrading of the ore. As shown in the Ellingham diagram for pure oxides (Figure 1), iron oxide can be selectively reduced over rare earth oxides. However, in the present case, smelting would be required to enable efficient separation of iron metal from the rare-earth oxide bearing slag. Rare earth oxides are stable under the iron smelting conditions generally described by the temperature and oxygen partial pressure, therefore they will report to the slag phase while the iron will report to the metal phase. However, the most important step is the extraction of the rare earths from the slag. Hydrometallurgical methods were investigated for this purpose.

In practice, smelting of the ore and solubilization of the rare earth oxides through acid leaching is affected by the ore mineralogy and impurities. The mineralogy of the ore affects the kinetics of both smelting and leaching.

\section{Principle of the PyEarth process}

The 'PyEarth' process flow sheet, as presented in Figure 2, incorporates the smelting of ore, leaching of rare earths from 


\section{Extraction of rare earths from iron-rich rare earth deposits}

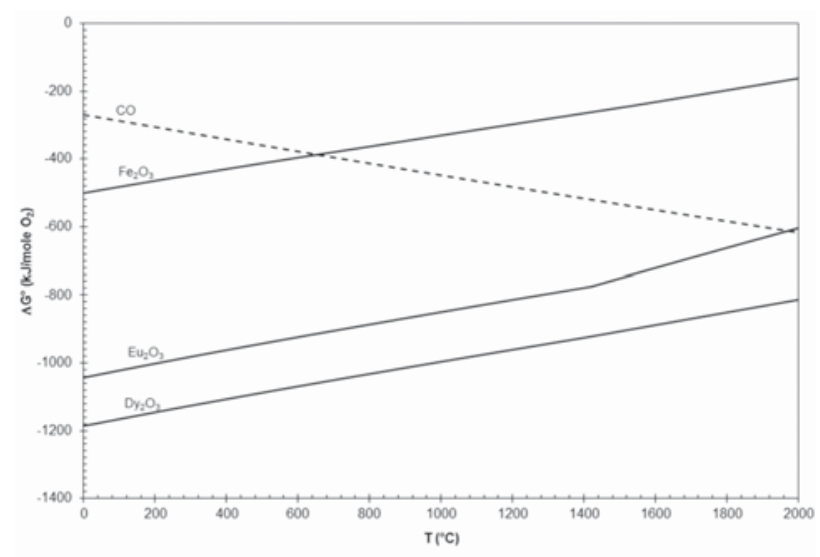

Figure 1-Ellingham diagram for pure oxides

the resulting slag, and recovery of the rare earths from the leach liquor. Smelting of the ore to a slag in which the REE are concentrated, as well as a metal product, followed by leaching of the slag, constitute the main critical steps of this process. In practice, there is more than one option/technique available for smelting, leaching, and recovery of rare earths from the solution. However, for simplicity, the flow sheet considers the use of a DC open-arc furnace to smelt the ore, leaching in a hydrochloric medium, precipitation of impurities, precipitation of the rare earths, and recovery of $\mathrm{HCl}$. As opposed to other smelting reactors such as blast furnaces and submerged-arc electric furnaces, the DC openarc furnace is able to process ore fines without prior preparation and the complex nature of the mineralogy is easily managed by way of temperature control. This reactor would be an appropriate option for the smelting of the mineralogically complex iron-rich, rare-earth-bearing ores.

Upgrading of the slag prior to leaching to remove constituents other than REOs is not included in the basic flow sheet presented in this paper. However, this option may improve the efficiency of the subsequent hydrometallurgical operations if physical upgrading (such as electrostatic and magnetic concentration, froth flotation, and gravity concentration) is introduced post-taphole.

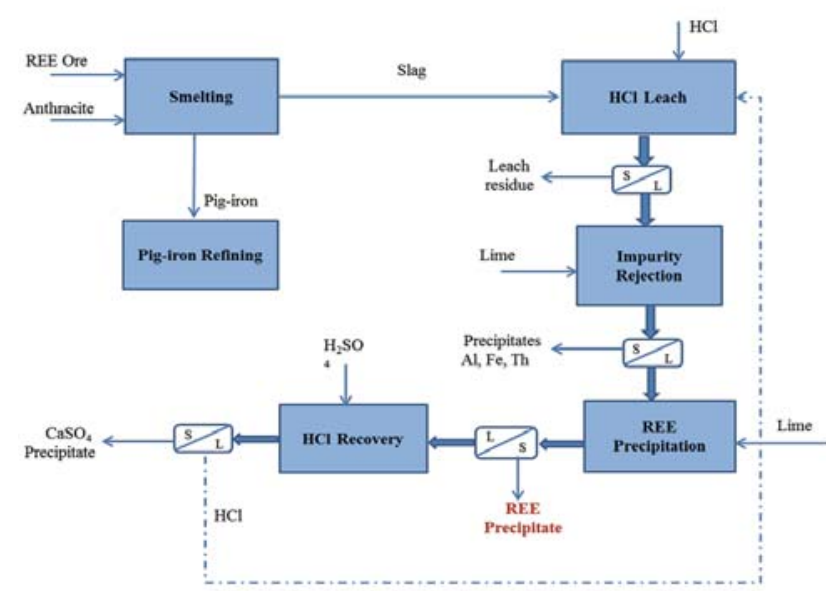

Figure 2-Proposed flow sheet for the PyEarthTM process

The results of preliminary smelting and leaching tests are presented and discussed in the following sections.

\section{Smelting}

\section{Raw materials}

A sample of iron-rich rare-earth-bearing ore from a Southern African deposit was subjected to series of laboratory tests. The bulk chemical composition was determined by simultaneous inductively coupled plasma-optical emission spectrometry (ICP-OES) (Varian Vista-PRO CCD), and the morphological and phase chemical compositions were determined by scanning electron microscopy (SEM) (Zeiss MA15 with energy-dispersive spectrometry (EDS) (Bruker) and X-ray diffractometry (XRD) (Bruker D8 Advance), respectively. The chemical composition of the ore is given in Table I, and the proximate analysis of the anthracite used as reductant is given in Table II. High-purity CaO was used as a fluxing agent to improve the smelting process, particularly to decrease the slag liquidus temperature and viscosity, constraints that are exacerbated at small scale.

\section{Table I}

Summary of the bulk chemical composition of the iron-rich rare earth ore

\begin{tabular}{|c|c|c|c|c|c|c|c|c|c|c|c|c|}
\hline & $\begin{array}{c}\mathrm{MgO} \\
(\%)\end{array}$ & $\begin{array}{c}\mathrm{Al}_{2} \mathrm{O}_{3} \\
(\%)\end{array}$ & $\begin{array}{c}\mathrm{SiO}_{2} \\
(\%)\end{array}$ & $\begin{array}{l}\mathrm{CaO} \\
(\%)\end{array}$ & $\begin{array}{c}\mathrm{TiO}_{2} \\
(\%)\end{array}$ & $\begin{array}{l}\mathrm{V}_{2} \mathrm{O}_{5} \\
(\%)\end{array}$ & $\begin{array}{c}\mathrm{Cr}_{2} \mathrm{O}_{3} \\
(\%)\end{array}$ & $\begin{array}{c}\mathrm{MnO} \\
(\%)\end{array}$ & $\begin{array}{c}\mathrm{FeO}(\mathrm{OH}) \\
(\%)\end{array}$ & S/A & $\mathrm{S} / \mathrm{M}$ & $\begin{array}{c}\mathrm{P}_{2} \mathrm{O}_{5} \\
(\%)\end{array}$ \\
\hline \multirow[t]{3}{*}{$\begin{array}{c}\text { Ore } \\
1\end{array}$} & 1.13 & 6.48 & 6.08 & 2.06 & 3.87 & 0.109 & 0.073 & 9.09 & 46.9 & 0.94 & 5.38 & 1.77 \\
\hline & $\mathrm{La}$ & $\mathrm{Ce}$ & $\operatorname{Pr}$ & $\mathrm{Nd}$ & $\mathrm{Sm}$ & Eu & Gd & Dy & Er & TREE & Th & $\mathrm{U}$ \\
\hline & $(\mathrm{mg} / \mathrm{kg})$ & $(\mathrm{mg} / \mathrm{kg})$ & $(\mathrm{mg} / \mathrm{kg})$ & $(\mathrm{mg} / \mathrm{kg})$ & $(\mathrm{mg} / \mathrm{kg})$ & $(\mathrm{mg} / \mathrm{kg})$ & $(\mathrm{mg} / \mathrm{kg})$ & $(\mathrm{mg} / \mathrm{kg})$ & $(\mathrm{mg} / \mathrm{kg})$ & $(\%)$ & $(\mathrm{mg} / \mathrm{kg})$ & $(\mathrm{mg} / \mathrm{kg})$ \\
\hline $\begin{array}{c}\text { Ore } \\
1\end{array}$ & 6060 & 10200 & 921 & 3900 & 478 & 145 & 435 & 166 & 99.8 & 2.34 & 221 & 71.6 \\
\hline $\begin{array}{l}\text { TREE: } \\
\text { Ho, Tn }\end{array}$ & $\begin{array}{l}\text { al rear ear } \\
\mathrm{u}, \mathrm{Yb}: \mathrm{RE}\end{array}$ & $\begin{array}{l}\text { ements } \\
\text { th concen }\end{array}$ & $1 \mathrm{~s} 1$ & $0 \mathrm{ppm}$ & $\begin{array}{l}\text { S/A } \\
\text { S/M }\end{array}$ & $\begin{array}{l}\text { of silica } \\
\text { of silica }\end{array}$ & $\begin{array}{l}\text { alumina } \\
\mathrm{MgO}\end{array}$ & & & & & \\
\hline
\end{tabular}

Table II

Summary of the bulk chemical composition of the anthracite (mass \%)

\begin{tabular}{|c|c|c|c|}
\hline Ash & Volatile & Fixed carbon & Total sulphur \\
\hline 4.74 & 6.19 & 89.1 & 0.56 \\
\hline
\end{tabular}




\section{Extraction of rare earths from iron-rich rare earth deposits}

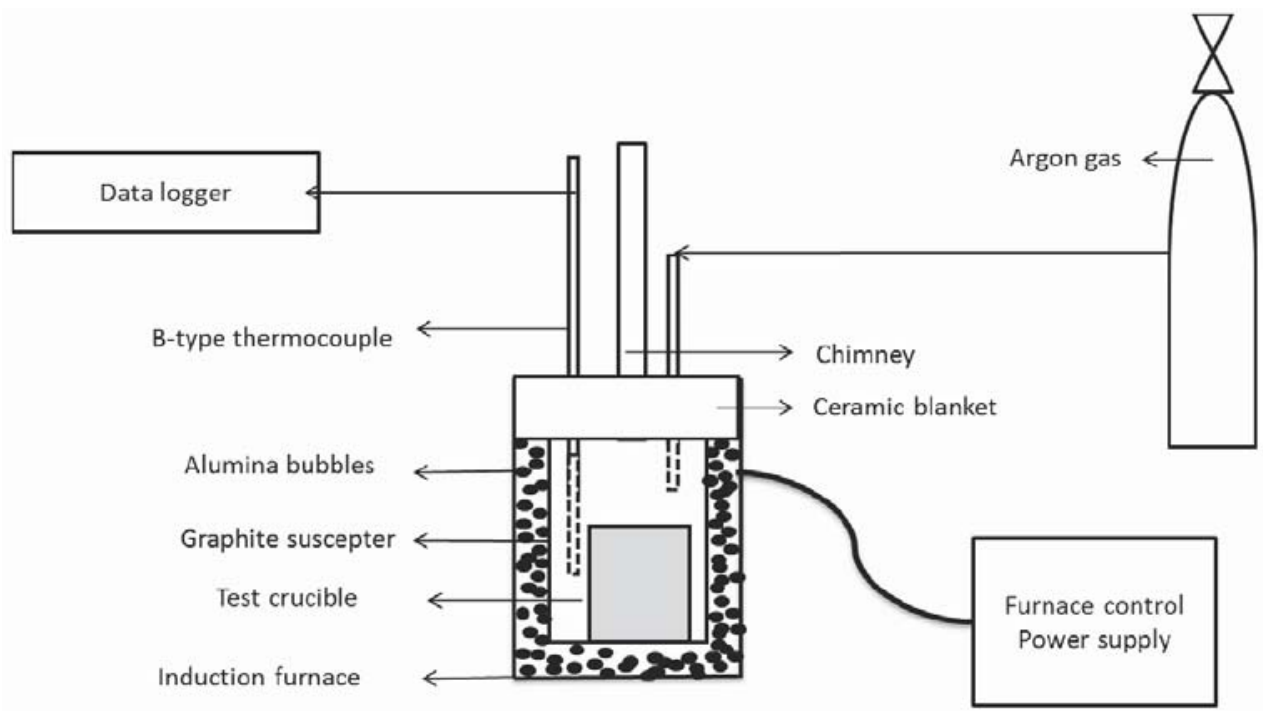

Figure 3-Schematic of the induction furnace experimental set-up

\section{Experimental procedure}

Laboratory smelting tests were conducted in $30 \mathrm{~kW}$ and 60 $\mathrm{kW}$ induction furnaces. Figure 3 shows a schematic of the induction furnace set-up.

The raw material components for the test conditions specified in Table III were blended and packed in a graphite crucible. Tests 1 and 2 were unfluxed tests conducted at stoichiometric anthracite addition and different temperatures. In this particular case, the anthracite amount was calculated so as to fully reduce the iron and manganese oxides. Tests 3 and 4 were fluxed with $0.5 \% \mathrm{CaO}$ with stoichiometric anthracite addition, and conducted at two different operating temperatures.

\section{Table III}

\section{Conditions for laboratory smelting tests}

\begin{tabular}{|c|c|c|c|}
\hline Test & Anthracite (\%) & $\mathrm{CaO}(\%)$ & Temperature $\left({ }^{\circ} \mathrm{C}\right)$ \\
\hline 1 & 100 & 0 & 1700 \\
\hline 2 & 100 & 0 & 1800 \\
\hline 3 & 100 & 0.5 & 1700 \\
\hline 4 & 100 & 0.5 & 1600 \\
\hline
\end{tabular}

The packed crucible was placed at the centre of the graphite susceptor in the induction furnace. A B-type thermocouple was secured next to the crucible, and argon gas was purged into the furnace to create an inert environment. The power was switched on and manually increased to attain a heating rate of $20-50^{\circ} \mathrm{C} / \mathrm{min}$ until the target temperature was reached. The crucible was held for about 30 minutes at the target temperature. The furnace power was then switched off and the crucible was left to cool in the Ar gas atmosphere inside the furnace. The cold crucible was removed, weighed, and then broken down to separate the metal and slag phases. The metal and slag samples were subjected to chemical and mineralogical analysis.

\section{Smelting results and discussion}

The mass balances for each smelting test, including the metal and slag masses, are given in Table IV. The smelting target was to achieve a slag with the highest REO grade as well as a clean separation between the slag and metal products.

Slag produced per unit of ore smelted and total REO grade of the slag product

The mass of slag generated per kilogram of ore smelted varied between 210 and $300 \mathrm{~g}$. On average, a mass of about

\begin{tabular}{|c|c|c|c|c|c|c|c|c|c|c|}
\hline \multicolumn{11}{|c|}{$\begin{array}{l}\text { Table IV } \\
\text { Mass balances for the smelting tests }\end{array}$} \\
\hline \multirow[b]{2}{*}{ Test } & \multirow{2}{*}{$\begin{array}{l}\text { Ore } \\
(\mathrm{g})\end{array}$} & \multirow{2}{*}{$\begin{array}{l}\text { Anthracite } \\
\text { (g) }\end{array}$} & \multirow{2}{*}{$\begin{array}{l}\mathrm{CaO} \\
(\mathrm{g})\end{array}$} & \multirow{2}{*}{$\begin{array}{c}\text { Total mass } \\
(\mathrm{g})\end{array}$} & \multicolumn{4}{|c|}{ Products (g) } & \multirow{2}{*}{$\begin{array}{c}\text { Total mass } \\
\text { out }(\mathrm{g})\end{array}$} & \multirow[t]{2}{*}{$T\left({ }^{\circ} \mathrm{C}\right)$} \\
\hline & & & & & Alloy+slag & Alloy & Slag & Gas/LOI & & \\
\hline & & & & & & & & & & \\
\hline 1 & 400.0 & 60.0 & 0 & 460.0 & 265.0 & 158.0 & 107.0 & 192.0 & 457.0 & 1700 \\
\hline 2 & 400.0 & 60.0 & 0 & 460.0 & 249.0 & 164.0 & 85.0 & 211.0 & 457.0 & 1800 \\
\hline 3 & 100.0 & 16.0 & 0.5 & 116.5 & 66.3 & 44.3 & 22.0 & 50.2 & 116.5 & 1700 \\
\hline 4 & 100.0 & 16.0 & 0.5 & 116.5 & 70.8 & 42.1 & 28.7 & 45.7 & 116.5 & 1600 \\
\hline
\end{tabular}




\section{Extraction of rare earths from iron-rich rare earth deposits}

$250 \mathrm{~g}$ was produced per kilogram of ore smelted. As with a physical method such as flotation, smelting is here used principally as a concentration step. Applying flotation terminology to this case, the slag product may be termed a concentrate and the metal tailings-although it is expected that the metal product may in fact have substantial economic value on its own merit. The mass pull, expressed in mass per cent, is the mass of concentrate produced per unit of ore processed. In this smelting case, a mass pull of $25 \%$ is achievable, depending on the ore composition, particularly the iron, manganese, and chromium contents, the loss on ignition, and the extent of smelting-reduction. The value of $25 \%$ can be considered as a baseline for concentration by smelting for this particular ore. The chemical analyses of the slags produced in the smelting tests are given in Table $\mathrm{V}$ and Table VI.

A slag with a total rare earth oxide (TREO) grade at least five times greater than that of the ore was achieved; which is a significant upgrading ratio. Slags containing up to $13.8 \%$ TREO were produced from ore with $2.5 \%$ TREO. A higher grade of TREO in the slag is desirable as this will decrease the amount of feed to the leaching process and thus improve the process economics. Of course, this needs to be balanced against the cost of the smelting step.

The smelting conditions were optimized at laboratory scale with regard to the contents of $\mathrm{FeO}$ and $\mathrm{MnO}$ in the slag and ultimately the amount of slag generated. This had an impact on the slag TREO grade. Within the scope of this test work, the optimal slag TREO grade of $13.6 \%$ was produced by smelting the ore at the highest temperature of about $1800^{\circ} \mathrm{C}$. However, addition of $0.5 \%$ lime to the smelting recipe produced a slightly higher slag grade of $13.8 \%$ TREO at a lower temperature of about $1700^{\circ} \mathrm{C}$. Operation at lower temperature as would result in furnace electricity savings.

\section{Alloy quality}

The compositions of the carbon-saturated iron-manganese alloys produced in these smelting tests are shown Table VII. Table VIII presents the rare earth contents of the alloys.
Other results (not presented here) indicated that the alloy composition is strongly related to manganese reduction. An increase in the extent of manganese reduction increases the manganese content of the alloy, while it decreases its iron concentration by dilution. Manganese oxide in the slag is deleterious as it increases the acid consumption in the subsequent leaching step. Therefore, its reduction to the alloy in the smelting step is desirable.

The reduction of manganese oxide is driven by a combination of the reductant addition, temperature, and slag basicity. The preferred alloy composition produced from ore 1 was $79-84 \% \mathrm{Fe}, 10-12.5 \% \mathrm{Mn}, 2-4 \%$ C, 3-6\% Si, and 0.7$1.3 \% \mathrm{P}$. This alloy composition falls within the composition range of commercial manganese steel, which consists of 11$13 \% \mathrm{Mn}$. The alloy may require $\mathrm{P}$ removal.

\section{Recovery of REO to the slag}

The recovery of TREO to the slag was calculated as the portion of the REO in the ore that reported to the slag phase. The highest content of total rare earth elements (TREE) in the metal was about 600 ppm, while the highest slag TREO was about $13.8 \%$. Within the scope of the present test work, and considering the above values, a recovery of rare earths to the slag of more than $95 \%$ was achieved. This confirmed that rare earth oxides are stable at the smelting conditions tested and fully reported to the slag phase, irrespective of the final slag grade.

\section{Smelting energy requirement}

The theoretical amount of energy required by a large-scale smelting process was calculated using FactSage software. FactSage predicted a furnace energy consumption in the range of 1.0-1.2 MWh per ton of ore. An electric arc furnace will be used to produce the rare-earth-rich slag and the iron alloy. The plant finances may be structured in such a way that the smelting energy cost is entirely covered by the sale of the alloy.

Table $\mathrm{V}$

REE content of the slags

\begin{tabular}{|l|c|c|c|c|c|c|c|c|c|c|}
\hline Test & $\begin{array}{c}\mathrm{La} \\
(\mathrm{mg} / \mathrm{kg})\end{array}$ & $\begin{array}{c}\mathrm{Ce} \\
(\mathrm{mg} / \mathrm{kg})\end{array}$ & $\begin{array}{c}\text { Pr } \\
(\mathrm{mg} / \mathrm{kg})\end{array}$ & $\begin{array}{c}\text { Nd } \\
(\mathrm{mg} / \mathrm{kg})\end{array}$ & $\begin{array}{c}\mathrm{Sm} \\
(\mathrm{mg} / \mathrm{kg})\end{array}$ & $\begin{array}{c}\text { Eu } \\
(\mathrm{mg} / \mathrm{kg})\end{array}$ & $\begin{array}{c}\text { Gd } \\
(\mathrm{mg} / \mathrm{kg})\end{array}$ & $\begin{array}{c}\text { Dy } \\
(\mathrm{mg} / \mathrm{kg})\end{array}$ & $\begin{array}{c}\mathrm{Ho} \\
(\mathrm{mg} / \mathrm{kg})\end{array}$ & $\begin{array}{c}\text { Er } \\
(\mathrm{mg} / \mathrm{kg})\end{array}$ \\
\hline 1 & 21601 & 42805 & 4328 & 19338 & 2327 & 829 & 1416 & 972 & 170 & 380 \\
\hline 2 & 29459 & 49500 & 5444 & 19144 & 2685 & 727 & 2420 & 1048 & 173 & 456 \\
\hline 3 & 28970 & 57197 & 5232 & 15077 & 2335 & 603 & 1816 & 785 & 153 & 364 \\
\hline 4 & 19429 & 32083 & 3569 & 12516 & 1756 & 550 & 1654 & 698 & 113 & 292 \\
\hline
\end{tabular}

\begin{tabular}{|l|c|c|c|c|c|c|c|c|c|}
\hline Test & $\begin{array}{c}\text { Tm } \\
(\mathrm{mg} / \mathrm{kg})\end{array}$ & $\begin{array}{c}\mathrm{Yb} \\
(\mathrm{mg} / \mathrm{kg})\end{array}$ & $\begin{array}{c}\mathrm{Lu} \\
(\mathrm{mg} / \mathrm{kg})\end{array}$ & $\begin{array}{c}\mathrm{Y} \\
(\mathrm{mg} / \mathrm{kg})\end{array}$ & $\begin{array}{c}\mathrm{Tb} \\
(\mathrm{mg} / \mathrm{kg})\end{array}$ & $\begin{array}{c}\text { Th } \\
(\mathrm{mg} / \mathrm{kg})\end{array}$ & $\begin{array}{c}\mathrm{U} \\
(\mathrm{mg} / \mathrm{kg})\end{array}$ & $\begin{array}{c}\text { REE } \\
(\%)\end{array}$ & $\begin{array}{c}\mathrm{RE}_{2} \mathrm{O}_{3}(\mathrm{REO}) \\
(\%)\end{array}$ \\
\hline 1 & 50.4 & 257 & 45.3 & 3904 & 139 & - & - & 9.86 & $\mathbf{1 1 . 6}$ \\
\hline 2 & 58.3 & 362 & 49.9 & 4547 & 275 & 863 & 210 & $\mathbf{1 1 . 6 0}$ & $\mathbf{1 3 . 6}$ \\
\hline 3 & 53.6 & 321 & 44.6 & 5015 & 210 & 986 & 256 & $\mathbf{1 1 . 8 0}$ & $\mathbf{1 3 . 8}$ \\
\hline 4 & 38.8 & 234 & 32.5 & 2536 & 195 & 862 & 452 & $\mathbf{7 . 5 7}$ & 8.87 \\
\hline
\end{tabular}




\section{Extraction of rare earths from iron-rich rare earth deposits}

Table VI

Other metal oxides in the slags, with total REO

\begin{tabular}{|c|c|c|c|c|c|c|c|c|c|c|c|c|c|c|}
\hline Test & $\mathrm{MgO}$ & $\mathrm{Al}_{2} \mathrm{O}_{3}$ & $\mathrm{SiO}_{2}$ & $\mathrm{CaO}$ & $\mathrm{TiO}_{2}$ & $\mathrm{~V}_{2} \mathrm{O}_{5}$ & $\mathrm{Cr}_{2} \mathrm{O}_{3}$ & $\mathrm{MnO}$ & $\mathrm{FeO}$ & BI & S/A & $\mathrm{S} / \mathrm{M}$ & REE & $\mathrm{RE}_{2} \mathrm{O}_{3}$ (REO) \\
\hline & $\%$ & $\%$ & $\%$ & $\%$ & $\%$ & $\%$ & $\%$ & $\%$ & $\%$ & & & & $\%$ & $\%$ \\
\hline 1 & 5.24 & 24.4 & 24.9 & 9.97 & 10.5 & 0.10 & 0.08 & 5.81 & 3.16 & 0.31 & 1.02 & 4.75 & 9.86 & 11.6 \\
\hline 2 & 7.74 & 29.6 & 18.3 & 13.6 & 4.40 & 0.108 & 0.089 & 4.69 & 1.39 & 0.45 & 0.62 & 2.36 & 11.6 & 13.6 \\
\hline 3 & 6.82 & 25.8 & 13.2 & 14.1 & 5.10 & 0.089 & 0.073 & 1.67 & 3.04 & 0.54 & 0.51 & 1.94 & 11.8 & 13.8 \\
\hline 4 & 5.74 & 19.9 & 22.8 & 10.1 & 11.4 & 0.089 & 0.073 & 5.24 & 4.64 & 0.37 & 1.15 & 3.97 & 7.57 & 8.87 \\
\hline
\end{tabular}

Table VII

Alloy analyses

\begin{tabular}{|l|c|c|c|c|c|c|c|c|c|c|c|c|c|}
\hline Test & $\begin{array}{c}\mathrm{Si} \\
(\%)\end{array}$ & $\begin{array}{c}\mathrm{Ti} \\
(\%)\end{array}$ & $\begin{array}{c}\mathrm{V} \\
(\%)\end{array}$ & $\begin{array}{c}\mathrm{Mn} \\
(\%)\end{array}$ & $\begin{array}{c}\mathrm{Cr} \\
(\%)\end{array}$ & $\begin{array}{c}\mathrm{Cu} \\
(\%)\end{array}$ & $\begin{array}{c}\mathrm{Ni} \\
(\%)\end{array}$ & $\begin{array}{c}\mathrm{Ca} \\
(\%)\end{array}$ & $\begin{array}{c}\mathrm{Fe} \\
(\%)\end{array}$ & $\begin{array}{c}\mathrm{Mg} \\
(\%)\end{array}$ & $\begin{array}{c}\mathrm{Al} \\
(\%)\end{array}$ & $\begin{array}{c}\mathrm{P} \\
(\%)\end{array}$ & $\begin{array}{c}\mathrm{C} \\
(\%)\end{array}$ \\
\hline 1 & 3.30 & 0.35 & 0.10 & 10.1 & 0.05 & 0.05 & 0.05 & 0.05 & 81.2 & 0.05 & 0.14 & 0.83 & 3.77 \\
\hline 2 & 0.78 & 0.67 & 0.11 & 12.0 & 0.08 & 0.03 & 0.04 & 0.19 & 83.9 & 0.09 & 0.34 & 0.73 & 4.09 \\
\hline 3 & 4.56 & 0.37 & 0.10 & 12.4 & 0.05 & 0.05 & 0.05 & 0.10 & 79.2 & 0.05 & 0.26 & 1.26 & 1.57 \\
\hline 4 & 1.72 & 0.39 & 0.13 & 11.4 & 0.04 & 0.05 & 0.04 & 0.09 & 81.5 & 0.04 & 0.26 & 0.69 & 3.68 \\
\hline
\end{tabular}

Table VIII

REE analyses of selected alloys

\begin{tabular}{|c|c|c|c|c|c|c|c|c|c|c|c|c|c|c|}
\hline Test & $\begin{array}{c}\mathrm{Ce} \\
(\mathrm{p}) \mathrm{pm}\end{array}$ & $\begin{array}{c}\mathrm{Dy} \\
(\mathrm{ppm})\end{array}$ & $\begin{array}{c}\mathrm{Er} \\
(\mathrm{ppm})\end{array}$ & $\begin{array}{c}\mathrm{Gd} \\
(\mathrm{ppm})\end{array}$ & $\begin{array}{c}\mathrm{La} \\
(\mathrm{ppm})\end{array}$ & $\begin{array}{c}\mathrm{Nd} \\
(\mathrm{ppm})\end{array}$ & $\begin{array}{c}\mathrm{Pr} \\
(\mathrm{ppm})\end{array}$ & $\begin{array}{c}\mathrm{Sc} \\
(\mathrm{ppm})\end{array}$ & $\begin{array}{c}\mathrm{Sm} \\
(\mathrm{ppm})\end{array}$ & $\begin{array}{c}\mathrm{Tm} \\
(\mathrm{ppm})\end{array}$ & $\begin{array}{c}\mathrm{Y} \\
(\mathrm{ppm})\end{array}$ & $\begin{array}{c}\mathrm{Yb} \\
(\mathrm{ppm})\end{array}$ & $\begin{array}{c}\mathrm{Th} \\
(\mathrm{ppm})\end{array}$ & $\begin{array}{c}\mathrm{U} \\
(\mathrm{ppm})\end{array}$ \\
\hline 1 & 250 & 5.26 & 1.96 & 15.9 & 143 & 123 & 31.3 & 17.8 & 1.32 & 10.7 & 1.18 & & 6.95 & 50.10 \\
\hline 3 & 155 & 2.80 & 1.49 & 7.00 & 98.9 & 59.2 & 18.3 & 66.4 & 8.22 & 1 & 15.4 & 1 & 8.65 & 31.5 \\
\hline
\end{tabular}

\section{Table IX}

Chemical analysis of the slag

\begin{tabular}{|c|c|c|}
\hline Element & Concentration & Unit \\
\hline $\mathrm{La}$ & 25120 & $\mathrm{mg} / \mathrm{kg}$ \\
\hline $\mathrm{Ce}$ & 49509 & $\mathrm{mg} / \mathrm{kg}$ \\
\hline $\mathrm{Pr}$ & 5022 & $\mathrm{mg} / \mathrm{kg}$ \\
\hline $\mathrm{Nd}$ & 18387 & $\mathrm{mg} / \mathrm{kg}$ \\
\hline $\mathrm{Sm}$ & 2722 & $\mathrm{mg} / \mathrm{kg}$ \\
\hline $\mathrm{Eu}$ & 986 & $\mathrm{mg} / \mathrm{kg}$ \\
\hline $\mathrm{Gd}$ & 1671 & $\mathrm{mg} / \mathrm{kg}$ \\
\hline $\mathrm{Dy}$ & 1118 & $\mathrm{mg} / \mathrm{kg}$ \\
\hline $\mathrm{Er}$ & 428 & $\%(\mathrm{w} / \mathrm{w})$ \\
\hline$T R E$ & 10.5 & $\mathrm{mg} / \mathrm{kg}$ \\
\hline $\mathrm{Th}$ & 738 & $\mathrm{mg} / \mathrm{kg}$ \\
\hline $\mathrm{U}$ & 234 & $\%(\mathrm{w} / \mathrm{w})$ \\
\hline $\mathrm{Mg}$ & 2.63 & $\%(\mathrm{w} / \mathrm{w})$ \\
\hline $\mathrm{Al}$ & 13.0 & $\%(\mathrm{w} / \mathrm{w})$ \\
\hline $\mathrm{Si}$ & 6.43 & $\%(\mathrm{w} / \mathrm{w})$ \\
\hline $\mathrm{Ca}$ & 6.32 & $\%(\mathrm{w} / \mathrm{w})$ \\
\hline $\mathrm{Ti}$ & 5.09 & $\%(\mathrm{w} / \mathrm{w})$ \\
\hline $\mathrm{Mn}$ & 3.03 & \\
\hline $\mathrm{Fe}$ & 7.39 & \\
\hline
\end{tabular}




\section{Extraction of rare earths from iron-rich rare earth deposits}

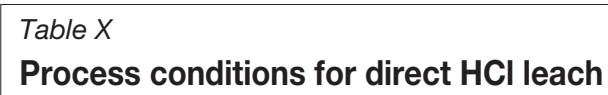

\begin{tabular}{|l|c|c|c|}
\hline Test number & $\begin{array}{c}\text { Solids content } \\
\%(\mathrm{~m} / \mathrm{m})\end{array}$ & $\begin{array}{c}\text { Acid dosage } \\
\mathbf{~ k g} / \mathbf{k g} \text { of slag }\end{array}$ & $\begin{array}{c}\text { Acid dosage } \\
\mathbf{k g} / \mathbf{k g} \text { of TREE }\end{array}$ \\
\hline 5 & 20 & 708 & 6.4 \\
\hline 6 & 10 & 861 & 7.8 \\
\hline 7 & 20 & 2201 & 20 \\
\hline 8 & 10 & 3445 & 31 \\
\hline 9 & 10 & 3445 & 31 \\
\hline
\end{tabular}

Temperature: $60^{\circ} \mathrm{C}$

Residence time: $2 \mathrm{~h}$

Grind size: $80 \%<35 \mu \mathrm{m}$

Table XI

Summary of actual operating conditions and extractions of REE and impurities

\begin{tabular}{|c|c|c|c|c|c|}
\hline Test & 5 & 6 & 7 & 8 & 9 \\
\hline Final temperature, ${ }^{\circ} \mathrm{C}$ & 61 & 61 & 59 & 59 & 59 \\
\hline Residence time, $\mathrm{h}$ & 2 & 2 & 2 & 2 & 2 \\
\hline Solids content, mass $\%$ & 20.0 & 9.4 & 20.0 & 8.9 & 8.9 \\
\hline Final pH & 1.00 & 0.00 & 0.07 & 0.00 & 0.00 \\
\hline Final Eh & 131 & -144 & -102 & 298 & 298 \\
\hline Acid dosage, $\mathrm{kg} / \mathrm{t}$ of slag & 708 & 861 & 2201 & 3445 & 3445 \\
\hline Acid dosage, $\mathrm{kg} / \mathrm{kg}$ of TREE & 6.4 & 7.8 & 20.0 & 31.3 & 31.3 \\
\hline Mass loss, $\%$ & 44.7 & 55.6 & 56.2 & 53.7 & 57.2 \\
\hline Grind size, $\%<35 \mu \mathrm{m}$ & 80 & 80 & 80 & 80 & 80 \\
\hline \multicolumn{6}{|c|}{ Solid-based metal extraction, mass $\%$} \\
\hline $\mathrm{Mg}$ & 27.0 & 46.1 & 46.7 & 40.5 & 44.9 \\
\hline $\mathrm{Al}$ & 57.6 & 69.7 & 69.5 & 66.6 & 69.4 \\
\hline $\mathrm{Si}$ & $<1$ & $<1$ & $<1$ & $<1$ & $<1$ \\
\hline $\mathrm{Ca}$ & 79.2 & 90.9 & 86.1 & 86.7 & 87.7 \\
\hline $\mathrm{Ti}$ & 27.6 & 45.1 & 49.1 & 44.9 & 49.3 \\
\hline $\mathrm{Mn}$ & 38.1 & 64.5 & 61.7 & 60.6 & 63.1 \\
\hline $\mathrm{Fe}$ & 93.4 & 95.7 & 94.5 & 95.4 & 95.4 \\
\hline Th & $\mathrm{N} / \mathrm{D}$ & 93.2 & 90.0 & 91.2 & 92.3 \\
\hline $\mathrm{U}$ & $\mathrm{N} / \mathrm{D}$ & 95.3 & 94.0 & 93.2 & 94.8 \\
\hline $\mathrm{La}$ & 93.8 & 96.8 & 95.1 & 95.9 & 96.1 \\
\hline $\mathrm{Ce}$ & 94.4 & 97.0 & 95.4 & 96.2 & 96.4 \\
\hline $\operatorname{Pr}$ & 93.5 & 96.6 & 94.8 & 95.6 & 95.9 \\
\hline $\mathrm{Nd}$ & 93.8 & 96.7 & 95.0 & 95.8 & 96.0 \\
\hline $\mathrm{Sm}$ & 94.1 & 97.0 & 95.4 & 95.9 & 96.2 \\
\hline $\mathrm{Gd}$ & 90.3 & 95.7 & 93.2 & 94.2 & 94.4 \\
\hline Dy & 93.7 & 97.4 & 95.8 & 96.3 & 96.4 \\
\hline Ho & 94.0 & 97.5 & 96.1 & 96.4 & 96.5 \\
\hline $\mathrm{Er}$ & 92.5 & 96.9 & 95.2 & 95.5 & 95.7 \\
\hline TREE & 93.8 & 96.8 & 95.1 & 95.9 & 96.1 \\
\hline
\end{tabular}




\section{Extraction of rare earths from iron-rich rare earth deposits}

\section{REE recovery from slag by leaching}

\section{Selection of leach procedure}

Initially, two classical treatment routes that are commonly used for REE recovery, namely caustic cracking followed by leaching of the REE with hydrochloric acid, and a sulphuric acid bake followed by a water leach, were evaluated for treating the slag (Gupta and Krishnamurthy, 2004).

The TREE extractions were relatively poor, yielding 49\% recovery for the caustic cracking route at a reagent dosage of $2000 \mathrm{~kg} \mathrm{NaOH}$ per ton of slag, and $41 \%$ at a reagent dosage of $2200 \mathrm{~kg} \mathrm{H}_{2} \mathrm{SO}_{4}$ per ton of slag for the sulphuric acid bake route.

A third leaching option, a direct hydrochloric acid leach, was then evaluated and subsequently selected as it yielded the best results, which are discussed in more detail below.

\section{Slag characteristics}

The slag produced in Test 1 was used as the feed for direct hydrochloric leaching tests. The concentrations of REE and major impurities are listed in Table IX. Minor REE are omitted.

\section{Experimental procedure for direct $\mathrm{HCl}$ leaching process}

The slag was milled to $80 \%<35 \mu \mathrm{m}$ prior to leaching. The milled slag was leached under four different process conditions at various acid dosages and pulp densities. Table $\mathrm{X}$ summarizes the various leaching conditions. Leaching was conducted by pulping the slag in $\mathrm{HCl}$ solution at $60^{\circ} \mathrm{C}$ with agitation. Operating parameters such as redox potential, temperature, and $\mathrm{pH}$ were recorded at regular intervals. After a leach duration of 2 hours, the pulp was filtered. The filter cake was washed thoroughly and subsequently dried, weighed, and analysed. The solution volumes were measured prior to analysis of the product liquors.

\section{Results and discussion}

The actual operating conditions as well as the solid-based leach extractions for REE and impurities are summarized in Table XI. The TREE leach efficiencies ranged between $94 \%$ and $97 \%$, and seemed largely insensitive to either pulp density or acid addition. At the lowest acid addition of 708 $\mathrm{kg} / \mathrm{t}$ slag, the REE recovery was lowest (94\%); however, the co-extraction of some impurities was also markedly depressed.

Nonetheless, due to the co-extraction of deleterious impurities such as $\mathrm{Al}, \mathrm{Ti}, \mathrm{Mn}, \mathrm{Fe}, \mathrm{Th}$, and $\mathrm{U}$, further treatment of the liquor prior to REE separation would be required. Although the TREE recovery was slightly lower, the results of the test conducted at $20 \%$ (w/w) pulp density at an acid addition of $708 \mathrm{~kg} / \mathrm{t}$ slag could be considered the most favourable. This is due not only to the lower lixiviant addition and associated lower lixiviant costs, but also to decreased neutralizing reagent requirements downstream for both the residual free acid as well as for impurities. In addition, a higher pulp density would allow a smaller equipment size and thus reduce the capital costs for this step.

\section{Mineralogy of slag and slag leach residue}

The REE were predominantly detected in the Ca silicate phases, with traces in the $\mathrm{Ba}-\mathrm{Ca}-\mathrm{Al}$ silicate phase and the $\mathrm{Ba}$ Ca silicate phase in the leach feed. Figure 4 shows the related backscattered electron image and EDS analysis.

Figure 5 shows the backscattered electron image and EDS analysis of the direct $\mathrm{HCl}$ leach residue. Residual REE, albeit at low concentrations, were detected in $\mathrm{Ca}$-Ti silicate phases and in $\mathrm{Ca}$-Al silicate phases Rare-earth-rich Ca silicate phases, which were the main REE-bearing phases in the slag prior to leaching, were not detected in the leach residue. The REE-bearing Ba-Ca-Al silicate phases were also not detected in the leach residue, which suggests that these phases are also amenable to attack by hydrochloric acid.
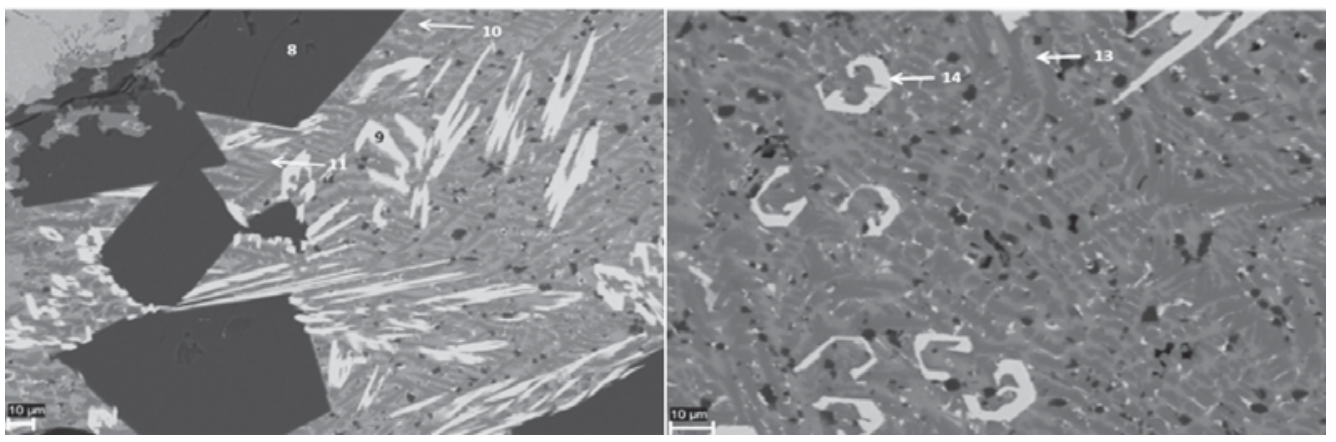

\begin{tabular}{|c|c|c|c|c|c|c|c|c|c|c|c|}
\hline Spectrum & $\mathbf{O}$ & $\mathbf{M g}$ & $\mathbf{A l}$ & $\mathbf{S i}$ & $\mathbf{S}$ & $\mathbf{C a}$ & $\mathbf{B a}$ & $\mathbf{L a}$ & $\mathbf{C e}$ & Nd & Phase \\
\hline 11 & 36.4 & & 14.8 & 16.3 & & 2.7 & 29.8 & & & & Ba-Al silicate \\
\hline 10 & 39.1 & & 17.0 & 12.3 & & 20.4 & 2.1 & 3.0 & 6.2 & & REE Ba-Ca-Al silicate \\
\hline 13 & 36.9 & 1.0 & 15.4 & 13.3 & 0.3 & 9.8 & 16.5 & & 6.7 & & REE Ba-Ca-Al -silicate \\
\hline 9 & 26.4 & & & 10.5 & 1.5 & 7.5 & & 15.9 & 26.8 & 11.5 & REE-Ca silicate \\
\hline 14 & 26.1 & & & 10.4 & 1.3 & 7.1 & 0.0 & 16.5 & 26.6 & 11.9 & REE-Ca silicate \\
\hline 8 & 44.7 & 19.4 & 35.9 & & & & & & & & Spinel \\
\hline
\end{tabular}




\section{Extraction of rare earths from iron-rich rare earth deposits}

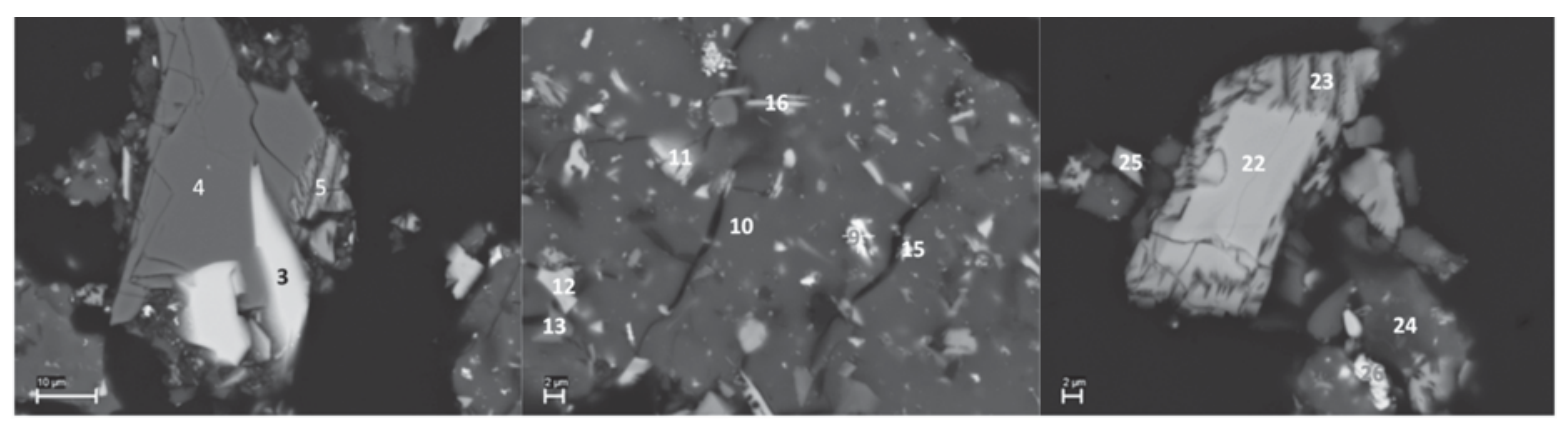

\begin{tabular}{|c|c|c|c|c|c|c|c|c|c|c|c|c|c|c|c|}
\hline Phase & Analysis & O & $\mathrm{Na}$ & $\mathrm{Mg}$ & Al & $\mathrm{Si}$ & $\mathbf{P}$ & $\mathrm{Ca}$ & $\mathrm{Ti}$ & Mn & $\mathrm{Fe}$ & $\mathrm{Zr}$ & $\mathrm{Ba}$ & $\mathrm{Ce}$ & $\mathrm{Nd}$ \\
\hline \multirow{4}{*}{ Ba silicate } & 3 & 38.3 & 0.36 & & 15.1 & 18.8 & & 0.26 & & & & & 27.2 & & \\
\hline & 1 & 32.2 & & 4.60 & 11.9 & 10.9 & & & & 7.60 & & & 31.6 & & \\
\hline & 11 & 37.1 & & 3.46 & 8.7 & 18.9 & & & & 9.70 & & & 20.7 & & \\
\hline & 15 & 42.7 & & & 0.7 & 22.9 & & 0.35 & & & & & 24.7 & & \\
\hline \multirow{5}{*}{ REE Ca-Al silicate } & 2 & 41.8 & & 4.10 & 14.1 & 14.6 & & 14.2 & 3.81 & 2.35 & & 0.67 & & 2.82 & 1.47 \\
\hline & 5 & 43.0 & & 4.73 & 12.4 & 17.4 & & 14.5 & 2.51 & 3.80 & & 0.81 & & 0.82 & \\
\hline & 22 & 41.7 & & 3.69 & 13.3 & 14.3 & & 14.3 & 5.95 & 2.28 & & 0.68 & & 2.45 & 1.40 \\
\hline & 23 & 42.7 & & 4.32 & 12.5 & 17.4 & & 15.6 & 1.75 & 4.13 & & 0.42 & & 0.81 & 0.34 \\
\hline & 25 & 42.8 & & 4.17 & 12.2 & 18.3 & & 13.7 & 1.37 & 4.74 & & 0.91 & & 1.29 & 0.57 \\
\hline REE Ca-Ti silicate & 9 & 38.0 & 1.56 & & 1.96 & 9.55 & & 9.30 & 28.8 & & & & & 7.92 & 2.94 \\
\hline \multirow[t]{2}{*}{ Low-REE silica } & 10 & 52.5 & 0.01 & & 0.63 & 43.8 & 0.22 & 0.20 & 2.48 & & & & & 0.12 & 0.02 \\
\hline & 24 & 51.6 & & 0.35 & 0.97 & 42.1 & & 0.49 & 2.59 & 0.63 & & 1.12 & & 0.15 & 0.00 \\
\hline REE-Ti silicate & 16 & 46.1 & & 2.65 & 5.59 & 24.5 & 0.19 & 0.17 & 12.21 & 4.49 & & & & 2.70 & \\
\hline \multirow{2}{*}{ Spinel } & 18 & 41.3 & & 12.32 & 31.3 & & & & 2.50 & 12.63 & & & & & \\
\hline & 4 & 43.4 & & 16.75 & 34.4 & & 0.04 & & 0.57 & 4.81 & & & & & \\
\hline
\end{tabular}

Figure 5-Backscattered electron image and EDS analysis of unfluxed test 1 leach residue

\section{Conclusions}

The PyEarthTM process was developed by Mintek to recover rare earth elements from iron-rich rare-earth-bearing carbonatite ores of complex mineralogy from Southern Africa.

The PyEarth process comprises two critical steps, namely smelting, which typically produces an Fe-Mn alloy as a potential saleable by-product and concentrates the rare earth oxides in the resulting slag, followed by leaching of the slag to recover the rare earths using hydrochloric acid.

The investigation successfully demonstrated that the smelting process can be operated as a pre-concentration step for REE. In addition, the Fe and Mn are converted into a potentially saleable by-product, whereas in the classical treatment routes large quantities of these would have to be discarded as tailings, with economic and environmental implications.

In the smelting step, close to full recovery of the rare earths to the slag is achieved, regardless of the REO grade of the final slag. A rare earth recovery in excess of $94 \%$ to the pregnant leach solution was attained using this process. Although some deleterious impurities are co-extracted from the slag, these would be removed downstream by conventional hydrometallurgical means. Process optimization is required, and future plans include test work at the pilot plant scale.

The laboratory test work showed that the PyEarth process is indeed a technically feasible, robust, and viable process for the extraction of rare earths from the mineralogically complex iron-rich rare-earth-bearing ores from the Southern African region.

\section{Acknowledgements}

This paper is published with the permission of Mintek.

\section{References}

GUPTA, C.K. and KRISHNAMURTHY, N. 2004. Extractive Metallurgy of Rare Earths. CRC Press, Boca Raton, FL.

Haque, N., Hughes, A., Lim, S., and Vernon, C. 2014. Rare earth elements: overview of mining, mineralogy, uses, sustainability and environmental impact. Resources, vol. 3. pp. 614-635.

Li, L.Z. and YANG, X. 2014. China's rare earth ore deposits and beneficiation techniques. Proceedings of the 1st European Rare Earth Resources Conference, Milos, Greece, 4-7 September 2014. pp. 28-39.

LoNG, K.R., vAN Gosen, B.S., Foley, N.K., and CoRDIER, D. 2010. The principal rare earth elements deposits of the United States. Scientific Investigations Report 2010-5220. US Geological Survey.

MisHRA, B. and ANDERSon, A. 2014. Extraction and recovery of rare-earth metals: challenges in processing. Proceedings of the 1st European Rare Earth Resources Conference, Milos, Greece, 4-7 September 2014. pp. 20-27.

WAnG, X., LeI, Y., GE, J., and Wu, S. 2015. Production forecast of China's rare earths based on Generalized Weng model and policy recommendations. Resources Policy, vol. 3, no. 4. pp. 11-18. 